\title{
HAV Immunity in Iranian Medical Students
}

\author{
Seyyed Javad Hosseini Shokouh ${ }^{1}$; Alireza Dadashi ${ }^{1}$; Mohamad Abiri ${ }^{1}$; Iraj zohrevand ${ }^{1}$; \\ Ahad Eshraghian ${ }^{1}$; Alireza Khoshdel ${ }^{2}$; Behnam Heidari ${ }^{1}$; Shayan Khoshkish ${ }^{1,{ }^{*}}$ \\ ${ }_{1}^{1}$ Infectious Diseases Research Center, AJA University of Medical Sciences, Tehran, IR Iran \\ ${ }^{2}$ Epidemiology Research Centre, AJA University of Medical Sciences, Tehran, IR Iran \\ ${ }^{*}$ Corresponding Author: Shayan Khoshkish, Infectious Diseases Research Center, AJA University of Medical Sciences, Tehran, IR Iran. Tel:+98-2122767954, Fax: +98-2122767955, E-mail: \\ khoshkishshayan@gmail.com
}

Received: December 19, 2014; Revised: February 1, 2015; Accepted: February 16, 2015

\begin{abstract}
Background:Hepatitis A, a fecal-oral transmitted disease, which has been considered endemic in developing countries, seems to change its pattern in developing countries because of their improved socioeconomic status.

Objectives: In the present study, we aimed to determine the need of vaccination in 270 students at AJA University of Medical Sciences.

Materials and Methods: The serum level of anti-HAV antibody was checked in 270 students of AJA University of medical students, and effect of different factors, including age, gender, pre-university entrance exam region, familial education, familial income, clean water availability, and previous history of jaundice were tested.

Results: Of total 270 students, 30 were female. Their age ranged between 18 and 30 years old with the mean age of 20.58 years and just $34 \%$ of students had positive level of anti-HAV antibody. Age and sex had no role in positive serum level of anti-HAV antibody. According to analyzed data, lack of clean water availability, pre-university entrance exam region, lower family education, and poor health status estimation increased statistically the risk of HAV infection.

Conclusions: Because $66 \%$ of students were anti-HAV antibody negative and they will work as health care workers in future, our study suggest vaccinating all students accepted at AJA University of Medical Sciences.
\end{abstract}

Keywords:Hepatitis A; Jaundice; Liver Failure; Acute

\section{Background}

Hepatitis A, a picornavirus, mainly infects the primates (1), and is mostly a fecal-oral transmitted disease $(2,3)$, with reported cases of transmission by IDU, sex with contaminated person, and blood transfusion (4). While Hepatitis $A$ is an endemic disease of developing countries, it has a different prevalence pattern in European countries depending on socioeconomic status $(5,6)$. Various studies revealed greater seropositivity in older patients (6-10). Childhood exposure is dominant in developing countries (7), whereas adults are more at risk of exposure and severe hepatitis in the developed world (11-13). Interestingly, improved socioeconomic status in developing countries leads to a rise in the mean age of exposure in developing countries $(2,14)$. There is no gender prominence for Hepatitis A(14), except for sewage workers or male homosexuals (15). Historically, outbreaks of HAV (hepatitis A virus) due to fecal-oral contamination of food and water have been reported. For instance, enteral related diseases like HAV caused health disasters of the Second World War $(15,16)$.

Antibodies to hepatitis A virus have been decreased in most parts of the world because of the improved socioeconomic status (17-19). Although infected children are asymptomatic, the infection is important in adults due to clinical manifestation HAV involvement $(2,16)$. Vaccination is not suggested in endemic countries, since they are protected due to childhood exposure (14). However, Averhoff et al. recommended early childhood vaccination, especially in developed countries (20). Vaccination is also highly recommended for travelers to endemic region (21). Anti-HAV immunoglobulin seroprevalence in Middle East is among the highest parts of the world like most parts of the Africa and South America (17). Heterogeneous prevalence of HAV in Saudi Arabia is dependent on the socioeconomic status (22), and its prevalence in some parts of Middle East like Turkey has decreased during these two decades $(17,23)$.

The prevalence of HAV in Iran resembles to other Middle Eastern countries in this regard and also believed to be endemic in Iran (24). We designed a survey to study the seroepidemiology of HAV among military students in AJA University of Medical Sciences originating from various regions in Iran. A Previous study performed among Iranian soldiers showed that vaccination is not necessary in them (25). Recent changes in seroepidemiological features of HAV due to improved health in Iran show increased HAV among the adults $(26,27)$.

Copyright (C) 2015, Kowsar Corp. This is an open-access article distributed under the terms of the Creative Commons Attribution-NonCommercial 4.0 International License (http://creativecommons.org/licenses/by-nc/4.0/) which permits copy and redistribute the material just in noncommercial usages, provided the original work is properly cited. 


\section{Objectives}

As these students are health care providers who have more prone to illnesses and also can infect others (28) and because $\mathrm{HAV}$ is preventable by vaccination, we aimed to reevaluate the necessity of vaccination in AJA medical students and also to find out the risk factors for Hepatitis A infection in our population.

\section{Materials and Methods}

All students accepted at AJA University of Military Medical Sciences in 2012-2014 academic years were enrolled in this study with no age and field of study limitation. Because they would work as health-care personnel in future, and may be at risk of HAV contamination; it was supposed to be a good target population for this study. All students were informed about the study and took part in the survey voluntarily. Students' data were collected with a questionnaire, designed specifically for this survey. Required data were age, area of resident, parents' education, socioeconomic level of living region according to government segmentation, number of family members, parents' job, family income, clean water availability, their estimation of region hygiene, their estimation of family hygiene, history of jaundice in them and their family. They had to complete the requested information before collection of their blood samples.

Two informed calibrated laboratory assistants were responsible for the collection of data and blood. They have used competitive enzyme-linked immunosorbent assay (ELISA) with sensitivity of $100 \%$ and specificity of $98 \%$ for the determination of immunoglobulin G (IgG) antibodies to hepatitis A virus in human plasma. Based on the guideline, tests were interpreted according to ratio of cut off value of OD450 $\mathrm{nm}$ of the samples and are assumed positive when the value is more than 1 and negative when the value is less than 1 .

Collected data were imported to SPSS version 18 and descriptive statistical analysis was performed. Following variables were analyzed using $\chi^{2}$ test: pre-university entrance exam region, familial income, clean water availability, health statues estimation, and history of jaundice. P value less than 0.05 considered as significant risk factor for positive anti-HAV antibody. Regression analysis was performed to interpret relationship between pre-university entrance exam region and anti-HAV antibody titer.

Table 1. Demographic Features of Study Population

\begin{tabular}{|c|c|c|c|}
\hline & Number of cases & Positive IgG-antibody & Negative IgG-antibody \\
\hline \multicolumn{4}{|l|}{ Sex } \\
\hline Male & 240 & 82 & 158 \\
\hline Female & 30 & 12 & 18 \\
\hline \multicolumn{4}{|c|}{ Socioeconomic level } \\
\hline 1 & 31 & 2 & 29 \\
\hline 2 & 140 & 37 & 103 \\
\hline 3 & 99 & 55 & 44 \\
\hline \multicolumn{4}{|c|}{ Father's education } \\
\hline Undereducated & 91 & 49 & 42 \\
\hline Diploma & 84 & 26 & 58 \\
\hline License & 67 & 17 & 50 \\
\hline Master & 20 & 2 & 18 \\
\hline PhD & 6 & 0 & 6 \\
\hline \multicolumn{4}{|c|}{ Mother's education } \\
\hline Undereducated & 119 & 60 & 59 \\
\hline Diploma & 95 & 21 & 74 \\
\hline License & 46 & 13 & 33 \\
\hline Master & 9 & 0 & 9 \\
\hline PhD & 0 & 0 & 0 \\
\hline \multicolumn{4}{|c|}{ Clean water availability } \\
\hline Yes & 259 & 84 & 175 \\
\hline No & 10 & 10 & 0 \\
\hline \multicolumn{4}{|c|}{ History of jaundice } \\
\hline Yes & 16 & 6 & 10 \\
\hline No & 253 & 88 & 165 \\
\hline
\end{tabular}




\section{Results}

We observed 270 medical students who voluntarily took part in our survey. Their age ranged between 18 and 30 years old with the mean age of 20.58 years. According to the sampling frame characteristics, 240 persons were male, and only 30 of them were female. None of the cases has been vaccinated against HAV and 15 have previously experienced jaundice, but HAV was not approved as the cause of jaundice in these cases.

Amongst 270 persons with known serum level of IgGanti HAV, 94 (33\%) cases had positive level of this antibody. We have summarized the demographic data of our study population in Table 1.

\subsection{Age}

All students admitted to AJA University of Medical Sciences between 2012 and 2014 and their age ranged from 18 to 30 years old. Mean age was 20.58 years and just two students were more than 24 years old. Because of the age limitation, interpretation of the age effect is not possible.

\subsection{Region of Students Inhabitant Before Univer- sity Entrance Exam}

We divided students into 3 categories based on the government regional socioeconomic territories. Thirty-one students live in the first socioeconomic level, 140 people lived in the second socioeconomic level and 99 lived in the third socioeconomic level. The detailed information about their region of living is summarized in Table 1, and living in the third region of pre-university entrance exam leads to increased risk of positive HAV antibody in contrast to the first and second regional levels $(\mathrm{P}<$ 0.001). Furthermore, the titer of the anti-HAV antibody in students living in the third group was also more than two other classes $(\mathrm{P}<0.001)$ (Figure 1$)$.

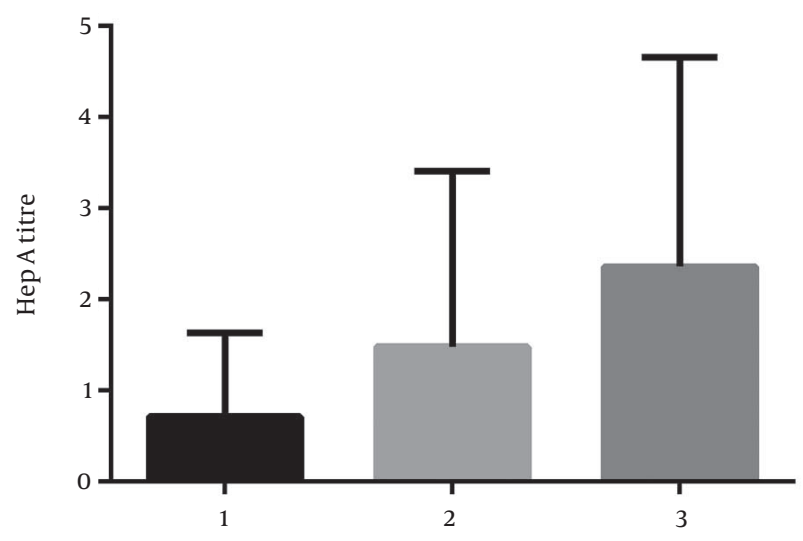

Figure 1. Relationship Between anti-HAV Antibody and Region of Living

\subsection{Familial Education}

Majority of fathers had diploma or were undereducated and just 6 fathers had PhD degree. Also mothers were mostly undereducated and none of them had PhD degree. Lower familial educational degrees in either fathers or mothers were associated with positive anti-HAV anti$\operatorname{body}(\mathrm{P}<0.001)$.

\subsection{Familial Income}

Thirty-nine students lived in the families with income less than $\$ 166$ per month, of which 18 were positive for anti-HAV antibody. On the other hand, among 22 students with familial income more than \$662, just one student had positive anti-HAV antibody. However, familial income was not found to be statistically associated with the greater risk of positive anti-HAV antibody.

\subsection{Clean Water Availability}

Just 10 students had no access to clean water in their living house. All of these 10 students were positive for antiHAV antibody. Absence of clean water availability seems to be a risk factor for HAV exposure and positive anti-HAV antibody $(\mathrm{P}<0.0001)$.

\subsection{Health Status Evaluation}

Students were asked about health status situation of their family and residence place. Both medium and poor situation of hygiene were associated with positive result, which was statistically significant $(\mathrm{P}<0.0001)$.

\subsection{History of Jaundice}

Just 2 out of 16 students with positive history of jaundice knew the cause of jaundice. No one reported hepatitis A as the cause of jaundice. Our analysis shows that history of previous jaundice is not a risk factor for positive anti-HAV antibody $(\mathrm{P}=0.89)$.

\section{Discussion}

In the present study, we evaluated the serum level of hepatitis A antibody of 270 students at AJA University of Medical Students, and its relationship with potential risk-factors. In this survey, socioeconomic status of living place, familial educational grade, students' estimation of regional, and familial health situation were statistically correlated with positive anti-HAV antibody. On the other hand, sex, age, and history of previous jaundice were not found as effective on serum titer of anti-HAV antibody. Our target group's age ranged between 18 and 30 years old, and their diversity is not appropriate for statistical analysis. Also the impact of gender and previous jaundice could not be interpreted with confidence due to our limited sample size. Total positive anti-HAV antibody in our survey was $34 \%$, which was lower than what is seen in Iranian soldiers (97\%) (25), or some other studies in 
Iran $(88.2 \%, 90 \%)(24,29)$. In another study conducted in general population in Sari, the total prevalence of positive anti-HAV antibody was $38.9 \%$ and was similar to ours (30). In another population based study performed in Isfahan Province, the anti-HAV seropositivity percentage was $8.33 \%$, even lower than that of our survey (31). In this survey, students have come from most parts of Iran, so it is better to divide them based on their origin to interpret this number.

Our study population consisted of young adults, ranging between 18 and 30 years old, from all around the country with different socioeconomic status. Because of this variety, our study differs from mentioned surveys. There were no close contacts in our population like what was seen in military services. In some studies, it is shown that the seropositivity increased as the population become older (32), but in our study population, difference in positive result in different age groups was not remarkable due to our age limitation. The lower immunity in younger age is a new finding in developing countries, and their immunity dynamically decreased by improving in health statues of these countries. Like other studies, gender was not a risk factor for seropositivity of anti-HAV antibody. Inaccessibility to clean water was a risk factor for Hepatitis A, like what Mosley et al. had showed previously (33), and all 10 students who had limited access to clean water were seropositive.

According to Das et al. the necessity of vaccination depends on total cost of vaccination, titer evaluation as well as serum-prevalence of anti-HAV antibody (34). Some studies in India believe that vaccination is necessary (35, 36 ), while other studies showed that vaccination was not necessary there $(7,10)$. These studies investigated the necessity of vaccination in childhood, however, our target population were 18-30 years old students with seroepidemiology less than 50\% (2). They were mainly health care providers, and vaccination in this population seems to be rational because of the side effects of HAV infection in adulthood and their proneness to infection.

It is necessary to design a study with no age limitation to determine anti-HAV antibody titer in different age groups. As more than $65 \%$ of students had negative serum level of anti-HAV antibody and these students as health care workers are susceptible to Hepatitis A and its side effects, we suggest vaccination of all military medical students.

\section{Acknowledgements}

We would like to thank Dr Pouria Heydarpour for his expert advice and encouragement throughout this project as well as our friend Dr Khalil Arefi.

\section{Authors' Contributions}

Ahad Eshraghian and Seyyed Javad Hosseini Shokouh developed the original concept. Shayan Khoshkish and Behnam Heidari reviewed the literature and prepared the questionnaire. Iraj Zohrevand and Mohamad Abiri collected the data. Alireza Dadashi, Shayan khoshkish and Behnam Heidari analyzed the data with the help of Alireza khoshdel. Shayan Khoshkish and Seyyed Javad Hosseini Shokouh revised and rewrote the manuscript. The study was supervised by Seyyed Javad Hosseini Shokouh.

\section{Funding/Support}

This project was financially supported by AJA University of Medical Sciences.

\section{References}

1. Balayan MS. Natural hosts of hepatitis A virus. Vaccine. 1992;10 Suppl 1:S27-31.

2. Mathur P, Arora NK. Epidemiological transition of hepatitis A in India: issues for vaccination in developing countries. Indian J Med Res. 2008;128(6):699-704.

3. Debord T, Buisson Y. [Viral hepatitis of enteric origin]. Bull Soc Pathol Exot.1998;91(5 Pt 1-2):428-31.

4. Fiore AE. Hepatitis A transmitted by food. Clin Infect Dis. 2004;38(5):705-15.

5. Frosner GG, Papaevangelou G, Butler R, Iwarson S, Lindholm A Courouce-Pauty A, et al. Antibody against hepatitis A in seven European countries. I. Comparison of prevalence data in different age groups. Am J Epidemiol.1979;110(1):63-9.

6. Kurkela S, Pebody R, Kafatos G, Andrews N, Barbara C, Bruzzone B et al. Comparative hepatitis A seroepidemiology in 10 European countries. Epidemiol Infect. 2012;140(12):2172-81.

7. Arankalle VA, Tsarev SA, Chadha MS, Alling DW, Emerson SU, Banerjee K, et al. Age-specific prevalence of antibodies to hepatitis A and E viruses in Pune, India, 1982 and 1992. J Infect Dis. 1995;171(2):447-50.

8. Termorshuizen F, Dorigo-Zetsma JW, de Melker HE, van den Hof $S$, Conyn-Van Spaendonck MA. The prevalence of antibodies to hepatitis A virus and its determinants in The Netherlands: a population-based survey. Epidemiol Infect. 2000;124(3):459-66.

9. Vancelik S, Guraksin A, Alp H. Hepatitis A seroepidemiology in Eastern Turkey. East Afr Med J. 2006;83(2):86-90.

10. Acharya SK, Batra Y, Bhatkal B, Ojha B, Kaur K, Hazari S, et al. Seroepidemiology of hepatitis A virus infection among school children in Delhi and north Indian patients with chronic liver disease: implications for HAV vaccination. $J$ Gastroenterol Hepatol. 2003;18(7):822-7.

11. Xu ZY, Li ZH, Wang JX, Xiao ZP, Dong DX. Ecology and prevention of a shellfish-associated hepatitis A epidemic in Shanghai, China. Vaccine. 1992;10 Suppl 1:S67-8.

12. Hutin YJ, Pool V, Cramer EH, Nainan OV, Weth J, Williams IT, et al A multistate, foodborne outbreak of hepatitis A. National Hepatitis A Investigation Team. N Engl J Med. 1999;340(8):595-602.

13. Willner IR, Uhl MD, Howard SC, Williams EQ, Riely CA, Waters B. Serious hepatitis A: an analysis of patients hospitalized during an urban epidemic in the United States. Ann Intern Med. 1998;128(2):111-4.

14. Chin KP, Lok AS, Wong LS, Lai CL, Wu PC. Current seroepidemiol ogy of hepatitis A in Hong Kong. J Med Virol.1991;34(3):191-3.

15. Gust ID. Epidemiological patterns of hepatitis A in different parts of the world. Vaccine. 1992;10 Suppl 1:S56-8.

16. Lednar WM, Lemon SM, Kirkpatrick JW, Redfield RR, Fields ML Kelley PW. Frequency of illness associated with epidemic hepatitis A virus infections in adults. Am J Epidemiol.1985;122(2):226-33.

17. Jacobsen KH, Koopman JS. Declining hepatitis A seroprevalence: a global review and analysis. Epidemiol Infect. 2004;132(6):100522.

18. Amela C, Pachon I, Bueno R, de Miguel C, Martinez-Navarro F. Trends in hepatitis A virus infection with reference to the process of urbanization in the greater Madrid area (Spain). EurJ Epidemiol.1995;11(5):569-73. 
19. Shapiro CN, Margolis HS. Worldwide epidemiology of hepatitis A virus infection. J Hepatol. 1993;18 Suppl 2:S11-4.

20. Averhoff F, Shapiro CN, Bell BP, Hyams I, Burd L, Deladisma A, et al. Control of hepatitis A through routine vaccination of children. JAMA. 2001;286(23):2968-73.

21. Mele A, Stroffolini T, Palumbo F, Gallo G, Ragni P, Balocchini E, et al. Incidence of and risk factors for hepatitis A in Italy: public health indications from a 10-year surveillance. SEIEVA Collaborating Group. J Hepatol. 1997;26(4):743-7.

22. Ramia S. Antibody against hepatitis A in Saudi Arabians and in expatriates from various parts of the world working in Saudi Arabia.J Infect. 1986;12(2):153-5.

23. Atabek ME, Fyndyk D, Gulyuz A, Erkul I. Prevalence of antiHAV and anti-HEV antibodies in Konya, Turkey. Health Policy. 2004;67(3):265-9.

24. Mohebbi SR, Rostami Nejad M, Tahaei SM, Pourhoseingholi MA, Habibi M, Azimzadeh P, et al. Seroepidemiology of hepatitis A and $E$ virus infections in Tehran, Iran: a population based study. Trans R Soc Trop Med Hyg. 2012;106(9):528-31.

25. Ghorbani GA, Alavian SM, Assari S. Seroepidemiology of Hepatitis A Virus in Iranian Soldiers in 2006: Do They Need Vaccination? Hepat Mon. 2007;7(1):7-9.

26. Salahei M, Ansari MA, Sanei ME, Khosravi S, Hajibeigi B, Alavian SM. The epidemiological pattern of acute viral hepatitis in Tehran and Zahedan: A comparison study. Gastroenterol Hepatol Bed Bench. 2009;3(1).

27. Movahedi M, Haghdoost AA, Pournik O, Hajarizadeh B, Fallah MS. Temporal variations of health indicators in Iran comparing with other Eastern Mediterranean Region countries in the last two de- cades. J Public Health (Oxf). 2008;30(4):499-504.

28. Keeffe EB. Occupational risk for hepatitis A: a literature-based analysis. J Clin Gastroenterol. 2004;38(5):440-8.

29. Saberifiroozi M. Hepatitis A virus infection: Is it an important hazard to public health?: hazards of HAV for public health. Hepat Mon. 2011;11(4):235-7.

30. Alian S, Ajami A, Ghasemian R, Yadegarinia D. Age-specific seroprevalence of hepatitis A in Sari, northern Islamic Republic of Iran. East Mediterr Health J. 2011;17(10):754-8.

31. Ataei B, Javadi AA, Nokhodian Z, Kassaeian N, Shoaei P, Farajzadegan $Z$, et al. HAV in Isfahan province: a population-based study. Trop Gastroenterol. 2008;29(3):160-2.

32. Jindal M, Rana SS, Gupta RK, Das K, Kar P. Serological study of hepatitis A virus infection amongst the students of a medical college in Delhi \& evaluation of the need of vaccination. Indian J Med Res. 2002;115:1-4.

33. Mosley JW, Schrack WJ, Densham TW, Matter LD. Infectious hepatitis in Clearfield County, Pennsylvania. I. A probable waterborne epidemic. Am J Med.1959;26(4):555-68.

34. Das A. An economic analysis of different strategies of immunization against hepatitis A virus in developed countries. Hepatology. 1999;29(2):548-52.

35. Mall ML, Rai RR, Philip M, Naik G, Parekh P, Bhawnani SC, et al. Seroepidemiology of hepatitis A infection in India: changing pattern. Indian J Gastroenterol. 2001;20(4):132-5.

36. Dhawan PS, Shah SS, Alvares JF, Kher A, Shankaran, Kandoth PW, et al. Seroprevalence of hepatitis A virus in Mumbai, and immunogenicity and safety of hepatitis A vaccine. Indian J Gastroenterol. 1998;17(1):16-8. 